\title{
Mucous change in the human duodenum: A light and electron microscopic study and correlation with disease and gastric acid secretion
}

\author{
W. J. A. PATRICK, D. DENHAM, AND A. P. M. FORREST \\ From the Department of Clinical Surgery, University of Edinburgh
}

SUMMARY The significance of mucous change in the human duodenum in a series of patients with peptic ulcer disease has been appraised. No specific correlation was demonstrated with the acid output of the stomach if the extent of the change is considered, but it was shown to be more common in the higher acid states. Electron microscopic studies confirmed the specific structure of the mucous cells of the duodenum and suggest that they arise either by transformation of Brunner's gland cells or as a distinctive population in the crypts.

It is suggested that the mucous change is a protective mechanism involved in some way as yet unknown with the healing of ulcers.

The partial replacement of the normal epithelial cells of the human duodenal mucosa by epithelial cells containing mucus was described in 1964 by James. He had first noticed mucous change in a biopsy of the second part of the duodenum in a patient thought to have the Zollinger-Ellison syndrome (James, 1963). These mucous cells were seen near the tips or on the sides of the villi and occasionally in the crypts. Invariably forming a characteristic grouping of three or four more cells in a row, they were clearly demarcated from the normal epithelial cells and from the goblet cells, which tend to be solitary. The change was found most frequently on atrophic or stunted villi and was accompanied by a chronic inflammatory cell reaction in the interstitial tissue. With higher magnification, the mucus was seen to be made up of smaller droplets and the cells appeared to lack the brush border. As they resembled the surface mucuscontaining cells of the gastric antrum, James termed the change 'gastric epithelium' and considered that it originated in the crypts (James, 1964).

Earlier Florey and Harding (1935) had demonstrated that artificial defects in the duodenal mucosa of cats healed by a simple mucous epithelium identical with gastric surface epithelium. In an experiment in pigs to investigate the ability of Brunner's glands to protect the duodenum from the destructive action of gastric juice, Florey, Jennings, Received for publication 29 May 1974.
Jennings, and O'Connor (1939) observed that many contiguous villi in duodenal loop fistulae draining Pavlov pouches of the body portion of the stomach were covered by mucus-containing cells similar to those lining the stomach. This was in contrast to the normal pig duodenum in which the mucous cells were observed only on scattered villi. Both groups of authors considered that the mucous cells originated in Brunner's glands.

The role of gastric acid in the production of mucous change was investigated by Rhodes (1964) who stimulated gastric acid secretion in cats by daily intramuscular injections of a suspension of histamine in beeswax and mineral oil. He demonstrated a higher incidence of 'gastric epithelium' in the duodenum of the stimulated animals. He also suggested that these cells grew on to the surface of the mucosa from Brunner's glands and believed that their purpose was to maintain the integrity of the surface layer against persistently high levels of acid.

A significant relationship between the severity of the overall histological change in duodenal mucosal biopsies and the level of gastric acid secretion was reported in a group of patients who on radiography had an abnormally coarse pattern of mucosal folds in the duodenum and gastric hypersecretion of acid (Rhodes, Evans, Lawrie, and Forrest, 1968). Although no attempt was made to correlate mucous change with acid secretion, it was suggested that the change probably resulted from damage to 
the mucosa and that it might protect the mucosa from ulceration. We have attempted to determine the significance of mucous change in man by relating it to disease of the duodenum and gastric acid secretion, and, by defining in detail the structure of the mucous cells, their possible origin.

\section{Material and Methods}

Anterior mucosal biopsies from the first part of the duodenum were obtained for histological examination from 117 patients at operation for suspected peptic ulcer disease. The biopsies were taken from an area clear of any recognizable pathological change.

In the 117 patients studied, 98 had peptic ulcer disease, four had pyloric stenosis of uncertain aetiology, and 15 had no evidence of peptic ulcer disease (table I). The number of peptic ulcer patients included 49 with active duodenal ulcers, 23 with duodenal scarring without active ulceration, 16 with gastric ulcers, and 10 with both gastric ulcers and duodenal ulcers or scarring. The numbers of non-peptic ulcer patients included eight with gastric carcinoma and seven with miscellaneous diseases, namely, gastric reticulum cell sarcoma, gastric lymphosarcoma, gastric leiomyosarcoma, gastric 'fibroma', redundant antral mucosal folds simulating gastric carcinoma and cholelithiasis with obstruction of the distal end of the common bile duct. One patient in whom no abnormality was found at laparotomy has been included in the miscellaneous group.

A group of 19 of the patients had biopsies taken from the first and second parts of the duodenum and $\mathbf{1 7}$ of these also had a biopsy taken from the third part. Twelve of the patients in this group had peptic ulcer disease and seven had disease other than peptic ulcer disease.

Another group of 12 of the patients with duodenal ulceration or scarring had biopsies taken from the edge of the ulcer or from the maximally scarred area as well as an anterior biopsy. Eleven of these patients had active duodenal ulcers and one had duodenal scarring without active ulceration.

Duodenal biopsies and tissue from the gastric antral mucosa from three patients with duodenal ulcers and from two patients with gastric cancer were processed for electron microscopy.

The biopsies for light microscopy were immersed immediately in $4 \%$ formaldehyde buffered to pH $7 \cdot 0-7 \cdot 4$ with $0 \cdot 1 \mathrm{M}$ phosphate buffer at room temperature. After fixation for 24 hours the tissue was trimmed with the aid of a dissecting microscope in order to ensure a vertical plane of section in the longitudinal axis of the villi and crypts. The tissue was processed by a routine histological method and embedded in paraffin wax (based on Culling, 1957). Sections $5 \mu \mathrm{m}$ thick were stained with aqueous periodic acid/Schiff reagent (McManus, 1946) and counterstained with haematoxylin (Mayer, 1904) and tartrazine.

The biopsies for electron microscopy were immersed immediately after excision in $2 \%$ glutaraldehyde (Sabatini, Bensch, and Barrnett, 1963), buffered to $\mathrm{pH} 7 \cdot \mathbf{0 - 7 \cdot 4}$ with $0 \cdot 1 \mathrm{M}$ phosphate buffer (Sörensen, 1909) at room temperature for primary fixation. The osmolality of the $2 \%$ glutaraldehyde fixative was $310-360 \mathrm{~m}-0 \mathrm{smols} / 1$ (freezing point depression Osmometer). Portions of the biopsies were transferred to formaldehyde and processed for light microscopy. After fixation in glutaraldehyde for one to two hours the tissue was trimmed into $1 \times 1 \times 2 \mathrm{~mm}$ blocks using a dissecting microscope. The total primary fixation time was four hours. The blocks were stored overnight in phosphate buffer at $4^{\circ} \mathrm{C}$ and then transferred for secondary fixation (Ledbetter and Porter, 1963) to $1 \%$ osmium tetroxide (Palade, 1952) in 0.1M phosphate buffer for one hour at $4^{\circ} \mathrm{C}$. After rinsing in phosphate buffer the tissue was dehydrated in a graded series of ethyl alcohols, 'cleared' in propylene oxide, infiltrated with Araldite (Glauert, Rogers, and Glauert, 1956) and embedded in Araldite contained in gelatin or plastic moulds. All stages in the processing and embedding procedures were carried out at room temperature. The Araldite in the moulds was allowed to polymerize over 24 to 48 hours at $60^{\circ} \mathrm{C}$ (based on Kay, 1965). Sections were cut with glass knives (Latta and Hartmann, 1950) on a LKB III ultramicrotome. Sections $1 \mu \mathrm{m}$ thick were stained with $0.5 \%$ aqueous toluidine blue (Trump, Smuckler, and Benditt, 1961). Thin sections with silver/grey interference colours of selected areas were mounted on uncoated copper grids, stained with uranyl acetate and lead citrate (Brody, 1959; Reynolds, 1963; Echlin, 1964), and examined in a Siemens electron microscope Elmiskop $1 \mathrm{~A}$, at an accelerating voltage of 60 or $80 \mathrm{kv}$. Specific areas were photographed using $30 \mu \mathrm{m}$ diameter thin foil objective apertures and instrument magnifications ranging from 2500 to 32000 .

Maximal gastric acid secretion was estimated preoperatively in 101 patients, either by the histamine infusion test (Lawrie, Smith, and Forrest, 1964), the pentagastrin infusion test (Multicentre Pilot Study, 1967), or the intramuscular pentagastrin simulation test (Johnston and Jepson, 1967). The tests formed part of the routine preoperative assessment of patients with suspected peptic ulcer disease in the departments in which this investigation was undertaken and give equivalent results. 
Only acid studies within six months of operation were used for correlation with the histological appearances. The results were expressed as the maximal acid output in m-equiv/h (Surgical Research Society, 1972).

The histological sections were examined primarily for focal, multifocal, or, diffuse mucous change. Focal mucous change was considered to be present if mucus-containing cells replaced normal epithelial cells in a localized area; multifocal change if two or more localized areas were separated by normal epithelium; and diffuse change if all the normal epithelial cells were replaced by cells of the mucuscontaining type. Mucous change in the crypts and in the villi was recorded separately.

The sections were also examined for evidence of oedema, epithelial damage, inflammatory cell reaction, villous and crypt atrophy, hyperplasia of Brunner's glands, and unsuspected microscopic ulceration in an attempt to relate mucous change to inflammatory, atrophic, hyperplastic, or reparative processes.

\section{Results}

\section{LIGHT MICROSCOPY}

The 117 biopsies from the first part of the duodenum included 86 from male patients and 31 from female patients. Mucous change (fig 1) was found in 68 of the biopsies. In 31 of these it was present on the villi or surface alone and in 36 it was present both on the villi and in the crypts. In only one biopsy was the change seen in the crypts and not on the surface.

The number of biopsies showing mucous change in various diseases are presented in table $I$. With the exception of one patient with pyloric stenosis of indeterminate origin, mucous change was found only in those with peptic ulcer disease. It was commoner in patients with active duodenal ulcers and duodenal scarring than in those with gastric ulcers.

The incidence of mucous change related to the maximal acid output in 101 patients is presented in

\begin{tabular}{lll}
\hline Disease & $\begin{array}{l}\text { Total Number of } \\
\text { Biopsies }\end{array}$ & $\begin{array}{l}\text { Numbers with } \\
\text { Mucous Change }\end{array}$ \\
\hline Duodenal ulcer & 49 & 38 \\
Duodenal scarring & 23 & 16 \\
Gastric ulcer & 16 & 7 \\
Gastric ulcer + duodenal ulcer & & \\
or scarring & 10 & 6 \\
Pyloric stenosis & 4 & 1 \\
Gastric carcinoma & 8 & 0 \\
Miscellaneous & 7 & 0
\end{tabular}

Table I Incidence of mucous change related to disease

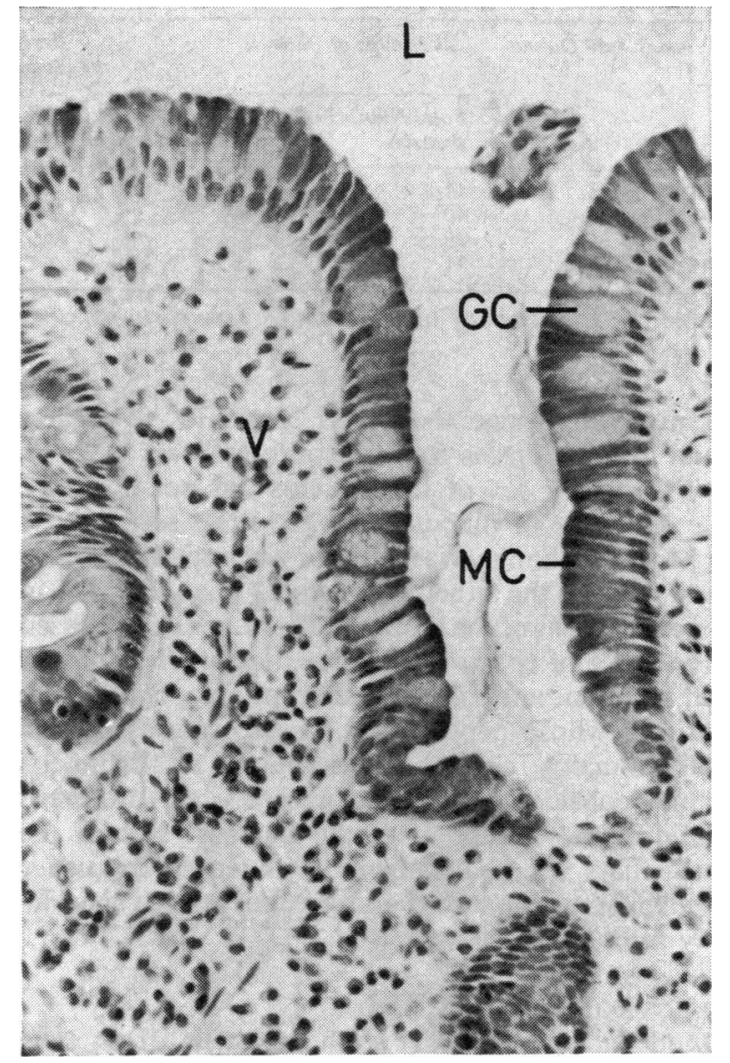

Fig 1 Mucous change in the human duodenum; characteristic groups of dark staining mucous cells $(M C)$ on the surface of a rounded villus $(V)$ with interspersed palestaining goblet cells $(G C) .(L=$ lumen $) . \times 80$.

table II. In general mucous change was more frequent in those patients with acid levels greater than $30 \mathrm{~m}$-equiv/h. In the case of the duodenal ulcer patients this was significant using Yates' correction for continuity $\left(\chi^{2}=4.66\right.$, dfl, $\left.0.025<P<0.05\right)$.

There was no specific relationship between the extent of mucous change and gastric acid secretion. The change occurred in multiple foci twice as often as in single foci. Diffuse change was rarely seen.

In the group of 19 patients who had biopsies taken from the first, second, and third parts of the duodenum, mucous change was observed only in those with peptic ulcers. This was present in the first part of the duodenum in eight out of 12 patients and in the second part, in one. Mucous change was not found in any of the 17 biopsies taken from the third part of the duodenum.

In the group of 12 patients with additional biopsies taken from the edge of active ulcers or area of maximal scarring, the incidence and extent 


\begin{tabular}{|c|c|c|c|c|c|c|}
\hline \multirow[t]{2}{*}{ Maximal Acid Output } & \multicolumn{2}{|c|}{ All Groups of Patients } & \multicolumn{2}{|c|}{$\begin{array}{l}\text { Patients with Duodenal Ulcers or } \\
\text { Scarring }\end{array}$} & \multicolumn{2}{|c|}{$\begin{array}{l}\text { Patients without Peptic Ulcer } \\
\text { Disease }\end{array}$} \\
\hline & $\begin{array}{l}\text { Total Number of } \\
\text { Biopsies }\end{array}$ & $\begin{array}{l}\text { Number with } \\
\text { Mucous Change }\end{array}$ & $\begin{array}{l}\text { Total Number of } \\
\text { Biopsies }\end{array}$ & $\begin{array}{l}\text { Number with } \\
\text { Mucous Change }\end{array}$ & $\begin{array}{l}\text { Total Number of } \\
\text { Biopsies }\end{array}$ & $\begin{array}{l}\text { Number w th } \\
\text { Mucous Change }\end{array}$ \\
\hline $\begin{array}{r}0-10 \\
11-30 \\
31-50 \\
51+\end{array}$ & $\begin{array}{l}11 \\
40 \\
39 \\
11\end{array}$ & $\begin{array}{r}0 \\
22 \\
33 \\
6\end{array}$ & $\begin{array}{r}0 \\
25 \\
35 \\
8\end{array}$ & $\begin{array}{r}0 \\
15 \\
31 \\
5\end{array}$ & $\begin{array}{l}8 \\
1 \\
0 \\
0\end{array}$ & $\begin{array}{l}0 \\
0 \\
0 \\
0\end{array}$ \\
\hline
\end{tabular}

Table II Incidence of mucous change related to maximal acid output

of mucous change there was found to be greater than in the biopsies from the anterior wall.

The age or sex of the patients did not influence the incidence of mucous change in this series.

Mucous change was always accompanied by at least one of the other histological changes used in the assessment of the biopsies. There was an increased prevalence of epithelial damage, acute inflammatory cell reaction, and villous and crypt atrophy in those patients whose peptic ulcer disease was associated with mucous change. Hyperplasia of Brunner's glands considered to be be present when Brunner's gland acini were seen on the mucosal side of the musculiars mucosa occurred with equal frequency in all groups of patients and was not related specifically to mucous change.

\section{ELECTRON MICROSCOPY}

Duodenal and antral epithelial cells from two patients with gastric cancer and three patients with duodenal ulcer were examined with the electron microscope.

Normally, the duodenal villi are covered by undifferentiated 'absorptive' cells and goblet cells and the crypts lined with undifferentiated cells, goblet cells, Paneth cells, and enterochromaffin cells.

The normal undifferentiated epithelial cells seen covering the villi were similar to those described by Trier and Rubin (1965). They were columnar cells with basal, longitudinally orientated, oval nuclei and regular microvilli projecting into the lumen along the upper border (fig 2a). An intercellular space separated adjacent cells except in a localized area close to the lumen where there was a tight junction (Farquhar and Palade, 1963). Contact between neighbouring cells was also maintained by means of desmosomes. The width of the intercellular space was variable and it was partly occluded by interdigitating cytoplasmic processes (fig $2 \mathrm{~b}$ ). Distension of the space often resulted in separation of the cytoplasmic processes and splitting of the desmosomes, but in all instances cellular contact was maintained at the tight junctions. The intercellular space was continuous with an electron transparent space (fig 2a) which separated the base of the cells from the basal lamina (Goel and Jurand, 1969).

The cytoplasmic structures were contained by a triple layered plasma membrane and the cells were coated along the microvillous border, and, to a lesser extent the lateral border, by a fine filamentous glycocalyx attached to the outer layer of the plasma membrane (Bennett, 1963; Ito, 1965) (fig 2b). The nucleus was enclosed by a well defined membrane. The structures in the supranuclear cytoplasm consisted of Golgi complex close to the nucleus, a few relatively large, darkly staining secretory granules, numerous elongated mitochondria, profiles of rough and smooth endoplasmic reticulum, scattered ribosomes, a few pinocytotic vesicles and multivesicular bodies (Duve and Wattiaux, 1966), and an extensive network of microtubules. The rough endoplasmic reticulum was closely associated with the mitochondria. Many of the pinocytotic vesicles were present in the apical cytoplasm and some of them opened on to the surface between microvilli while others opened into the intercellular space. The core of the microvilli consisted of fine fibrils which extended into the apical cytoplasm to form the terminal web. The pleomorphic secretory granules, which were larger than the multivesicular bodies, were enclosed by a membrane. Some of the secretory granules were pale staining with a fibrillar structure but the granules mainly had a dark, unevenly staining, particulate appearance (fig $2 b$ ).

The infranuclear cytoplasm contained fewer profiles of endoplasmic reticulum, more numerous free ribosomes, more frequent and closer packed mitochondria, and some pinocytotic vesicles, but no multivesicular bodies or secretory granules (fig 2a).

The villous epithelial cells in which mucous change had occurred (fig 3) were generally similar in size and structure to normal undifferentiated epithelial cells, but they had irregular microvilli, many secretory granules in the supranuclear cytoplasm, and aggregates of glycogen (Fawcett, 1958) and vesicles resembling fat in the infranuclear cytoplasm. Many of the cells showed irregular indenta- 


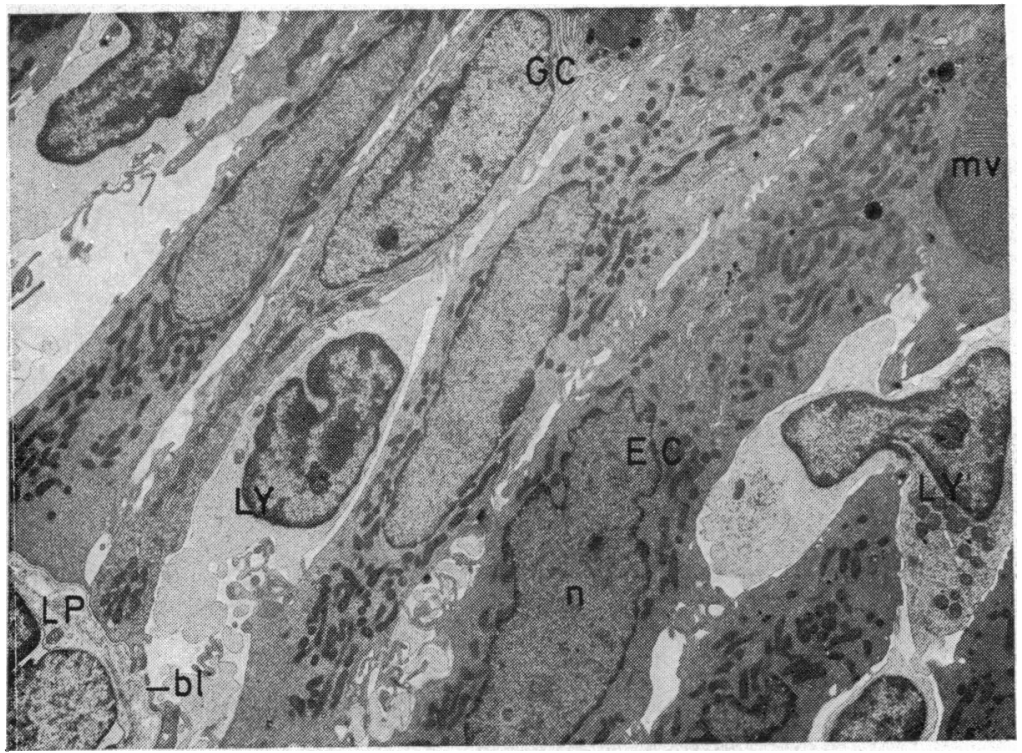

Fig 2a Normal villous epithelium with undifferentiated columnar epithelial cells (EC), goblet cells (GC), and intraepithelial lymphocytes $(L Y) .(n=$ nucleus, $m v=$ microvilli, $b l=$ basal lamina, $\boldsymbol{L P}=$ lamina propria) $\times 3000$.

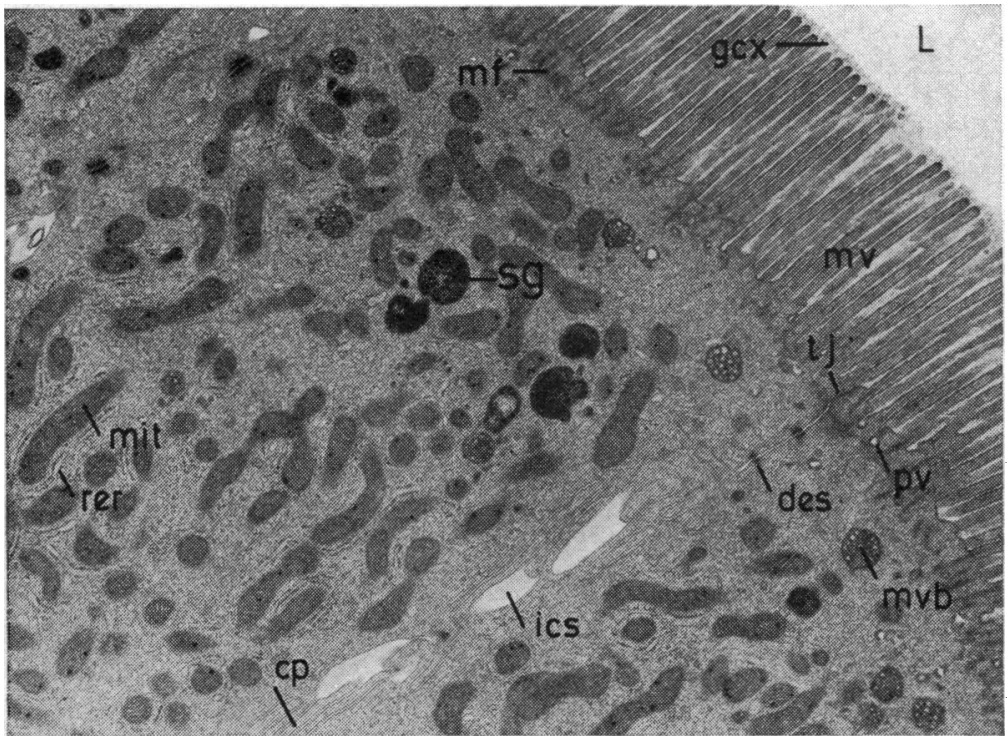

Fig 2b Apical part of normal villous epithelial cell with occasional secretory granules (sg). ( $L=$ lumen, $m v=$ microvilli, ics $=$ intercellular space, $t j=$ tight junction, des $=$ desmosomes, $c p=$ cytoplasmic processes, $g c x=$ glycocalyx, mit = mitochondria, rer $=$ rough endoplasmic reticulum, $p v=$ pinocytotic vesicles, $m v b=$ multivesicular bodies, $m f=$ micro filaments). $\times 8000$.

tions of the microvillous border which contained material similar to that of the secretory granules. Frequently, secretory granules were seen to be bulging into the indentations or protruding between the microvilli but no discharge of the contents of the granules was observed. The plasma membrane overlying some of the protruding granules was distorted and empty membranous vesicles were often present in the lumen close to the microvilli.

Mucous cells were present in some of the crypts.
The mucous crypt cells (fig 4) were similar to those on the villi but they had fewer secretory granules and fewer microvilli. The secretory granules had a clearly defined triple layered limiting membrane. In the sections studied distortion of the plasma membrane overlying protruberant granules and empty membranous vesicles in the lumen occurred but indentation of the apical cytoplasm and extracellular material resembling that in the secretory granules was not observed.

The structure of the mucous cells is different 


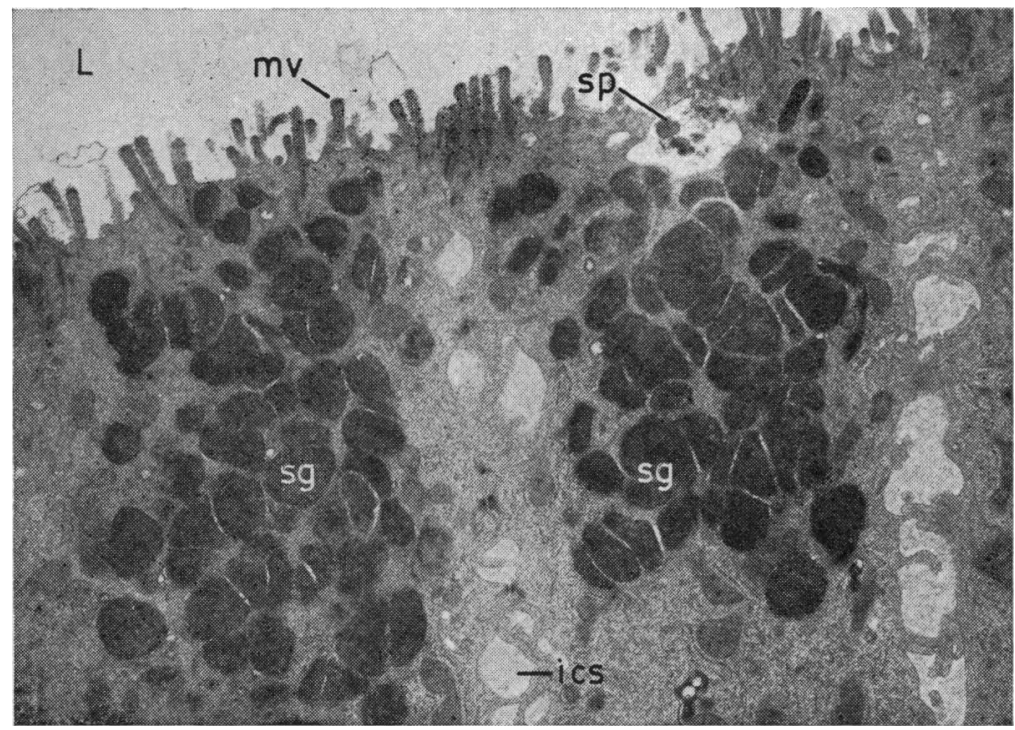

Fig 3 Villous epithelial cells showing mucous change. The apical cytoplasm contains many secretory granules (sg), the microvillous border is indented and the plasma membrane overlying protruding secretory granules is distorted. Material $(s p)$ similar to that of the secretory granules is seen within the indented portion of the microvillous border. The microvilli are irregular. ( $L=$ lumen, $m v=$ microvilli, ics $=$ intercellular space). $\times 8000$.

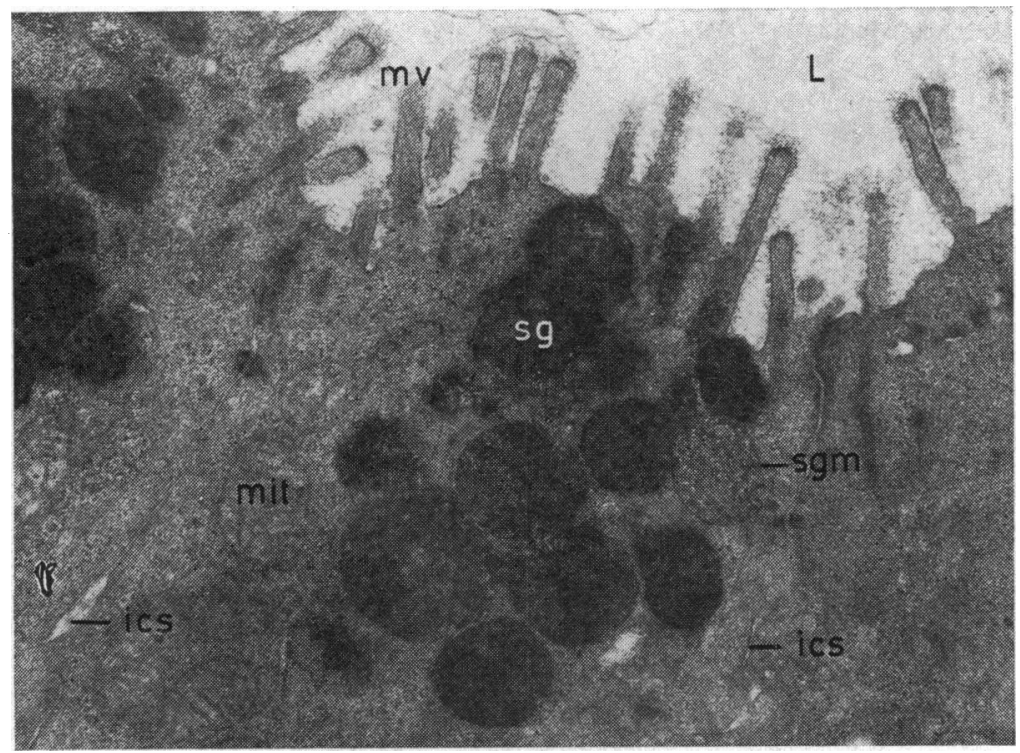

Fig 4 Apical part of mucous cells in a crypt with fewer secretory granules (sg). The secretory granules are bound by a triple layered membrane (sgm) and some of the granules protrude between microvilli. ( $L=$ lumen, $m v=$ microvilli, ics $=$ intercellular space, mit $=$ mitochondria).$\times 16000$

from that of goblet cells (Freeman, 1968) and the cells of Brunner's gland acini or ducts. Goblet cells examined had a horizontally orientated, frequently crescent-shaped basal nucleus and a supranuclear mass of tightly packed light- and dark-staining secretory granules. The mass of secretory granules distended the cell and displaced the other cytoplasmic structures, which included a relatively abundant endoplasmic reticulum. The cells had a peripheral arrangement of microvilli around a stoma-like apical portion of the cell.

The acinar cells of the Brunner's glands were cuboidal shaped with an oval, horizontally orientated basal nucleus. The cytoplasmic components were dispersed between large, pale-staining secretory granules. The secretory granules had a characteristic eccentric darkly staining focus which merged imperceptibly with the rest of the granule. The granules 


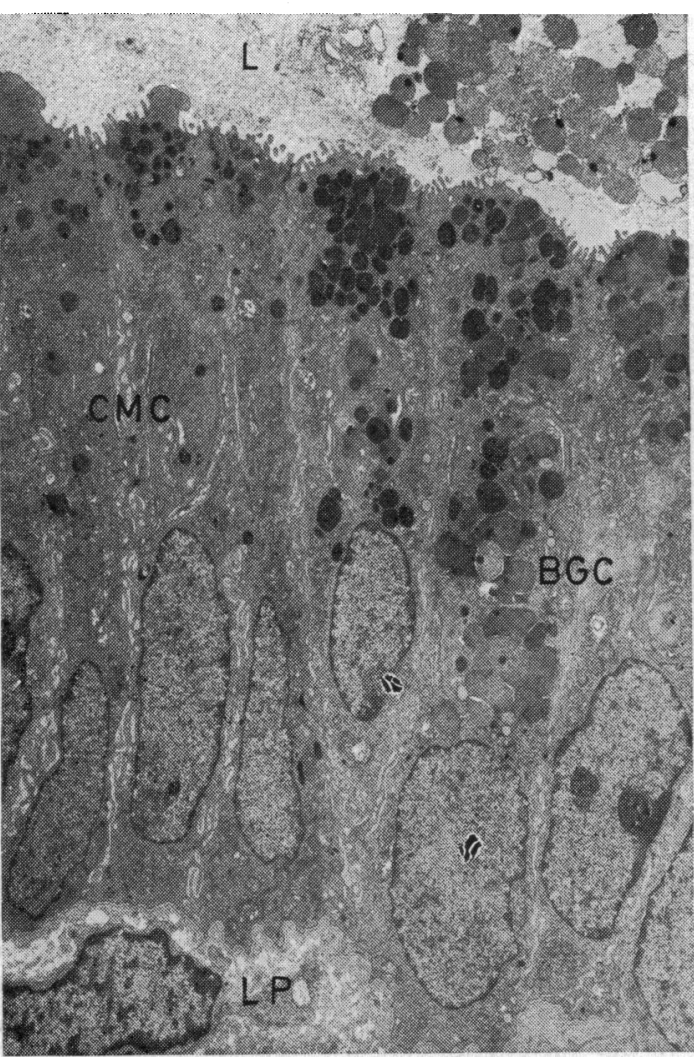

Fig 5 The transition zone between a hyperplastic Brunner's gland $(B G C)$ and a crypt with mucous change (CMC). The cells have features of both mucous cells and Brunner's gland cells. ( $L=$ lumen, $L P=$ lumen propria $). \times 3000$.

were enclosed by a limiting membrane though some of them appeared to have coalesced to exclude the intervening membrane. The upper border of the cells contained sparse stunted microvillous projections.

Where ducts of hyperplastic Brunner's glands opened into crypts containing mucous cells, there was a transition zone where cell types merged (fig 5). But, despite this merging of cell types, the structure of Brunner's gland cells and mucous cells was quite distinct.

The cells which the mucous cells of the duodenum most closely resembled were the surface cells of the gastric antrum (Lillibridge, 1964), which were similarly columnar shaped with a basal, longitudinally orientated, oval nucleus and abundant secretory granules in the supranuclear cytoplasm (fig 6). They had irregular microvilli coated with glycocalyx, were separated by a variable intercellular space, and rested on a basal lamina. Like the mucous cells in the duodenum glycogen particles

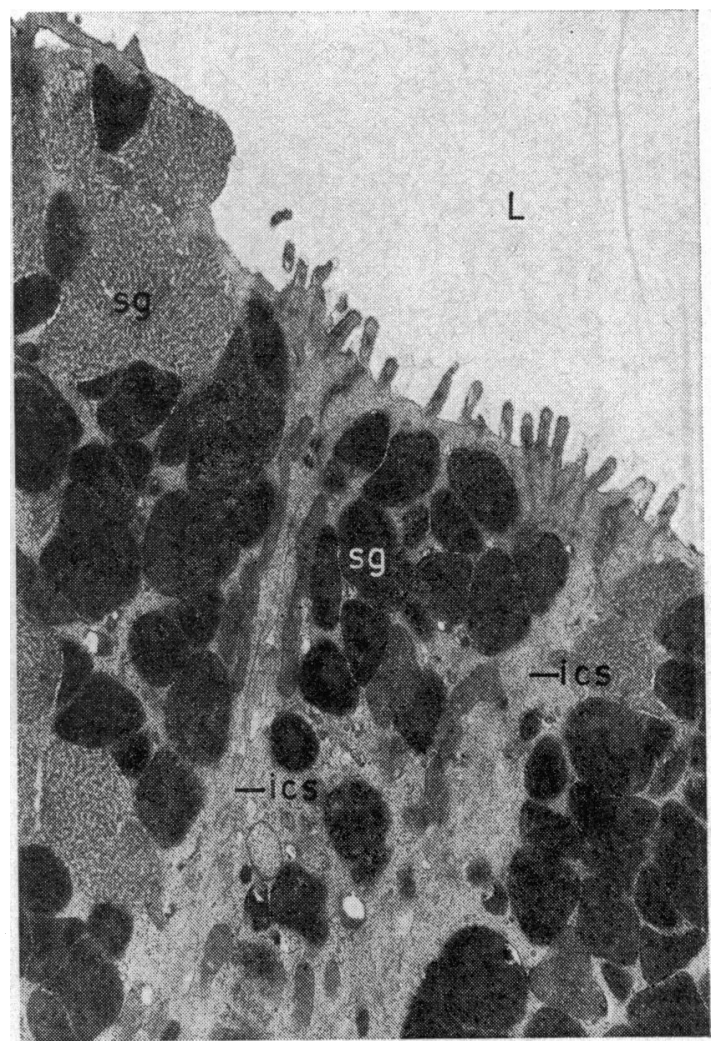

Fig 6 Apical part of the surface cells of the gastric antrum which the mucous cells of the duodenum most closely resemble. $(L=$ lumen, ics $=$ intercellular space, $s g=$ secretory granules). $\times 8000$.

were present in the infranuclear cytoplasm. The secretory granules were both pale and dark staining and were limited by a triple layered membrane (figs 6 and 7). Distortion of the plasma membrane overlying the paler secretory granules was frequently seen. There were many membranous vesicles free in the lumen and attached to the altered plasma membrane. The appearance suggested that the plasma membrane was the origin of the vesicles.

Secretion of the surface cells of the gastric antrum occurred by the discharge of the contents of individual secretory granules through the apical portion of the cells (fig 7). By a series of undefined intermediate steps, the membrane surrounding the secretory granule appeared to break and unite with the plasma membrane, enabling the contents to pass out into the lumen. The changes in the plasma membrane overlying the pale secretory granules and the formation of membranous vesicles might be stages in this process. 


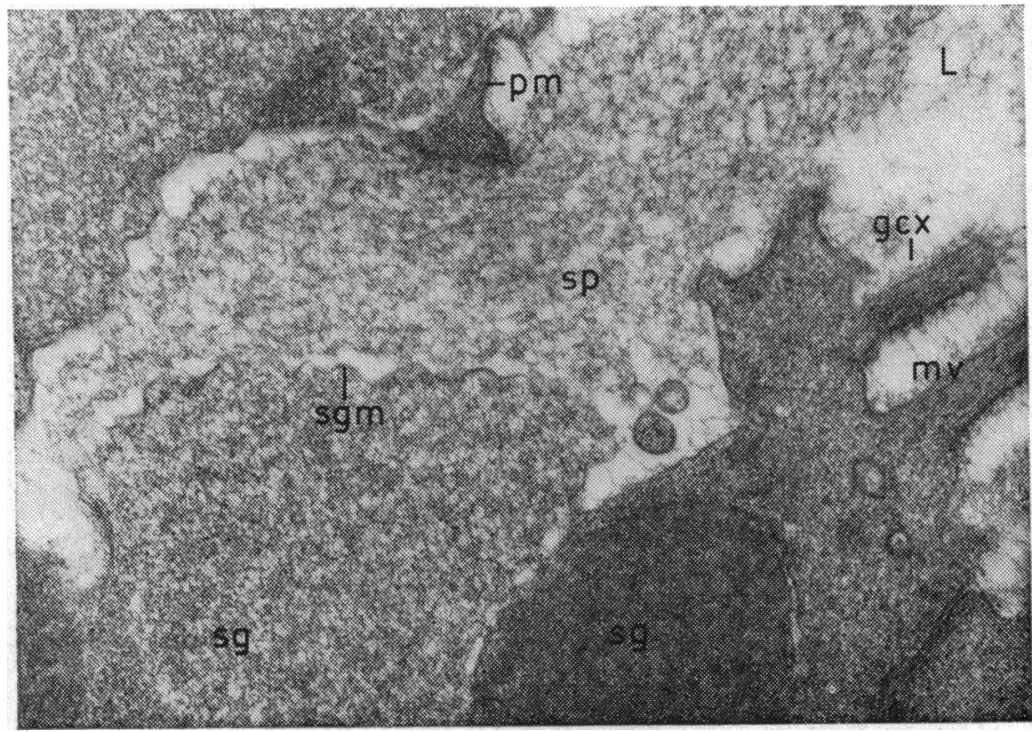

Fig 7 Discharge of the content (sp) of a secretory granule through the apical part of a surface cell of the gastric antrum. ( $L=$ lumen sg $=$ secretory granule, $s p=$ secretory product, sgm = secretory granule membrane, $p m=$ plasma membrane, $m v=$ microvilli, $g c x=$ glycocalyx). $\times 32000$.

\section{Discussion}

The results of the histological survey show that mucous change was present in $75 \%$ of cases with duodenal ulcers and in $44 \%$ of cases with gastric ulcers. It was rarely seen beyond the first part of the duodenum and was usually more extensive in areas close to ulcers. The figures can only be assessed as absolute percentages as the numbers of cases are too variable for statistical evaluation. The results are in agreement with those of James (1964).

The relation of mucous change to gastric acid secretion is speculative. In the quoted cases the incidence of the change was significantly greater in duodenal ulcer patients with high acid levels. Although the incidence of mucous change was higher in the higher acid range the extent of the change was not. It would be reasonable to assume that had the change been specifically related to acid output, then the extent of the change would also have been greater in the higher acid states.

The electron microscopic studies confirm and enlarge the specific structural differences of the mucous cell described by James (1964). As far as is known, this is the first electron microscopic description of these cells. James reasoned that as intestinal epithelium is renewed by cell division in the crypts followed by migration to the villi rather than by random mitosis, it was unlikely that the function of the adult cells would be able to change from an accepted absorptive role to an assumed protective one on the single life span of the cells. He suggested that the cells arose from the crypts in the same way as normal epithelial cells in response to injury or acid or a combination of both. Florey and his colleagues and Rhodes, by contrast, believed that the mucous epithelium originated in Brunner's glands; they based their belief basically on the apparent continuity, in places, of Brunner's glands with the intestinal glands and the surface epithelium showing mucous change. The present electron microscopic analysis has demonstrated this continuity between the ducts of hyperplastic Brunner's glands and crypts containing mucous change with a transition zone in which there are epithelial cells with features of both Brunner's glands and mucous change. It is possible that the cells of the ducts of Brunner's glands transform into mucous cells in the crypts before they migrate on to the villi. However, it is also possible that the mucous cells arise as a distinct population in the crypts, for the mucous cells in the crypts closely resemble undifferentiated crypt cells.

Active secretion by undifferentiated jejunal crypt epithelial cells was demonstrated by Trier in 1964. Using peroral biopsies of the proximal jejunum in man he showed that membrane-bound secretory granules were present in the apical cytoplasm of undifferentiated crypt cells and that the contents of the granules was delivered into the crypt lumen by fusion of the apical cell membrane with the membrane surrounding the secretory granules. This mechanism of secretion is identical to that seen in the mucous cells on the surface of the gastric antrum and described in the text. Although Trier thought that an apocrine type of secretion might also occur, 
the merocrine type of secretion he described in the jejunum is similar in many aspects to the changes which suggest secretion in the mucous cells of the duodenum, namely, indentation of the apical cytoplasm, protrusion of the secretory granules, secretory granule-like material in the indentations, and distortion of the plasma membrane.

The secretory granules seen with the electron microscope correspond to the periodic acid/Schiffpositive-staining granules in the cytoplasm of the undifferentiated epithelial cells in the crypts of the duodenum (Doniach and Shiner, 1957) and the jejunum (Trier, 1963) and of the mucous cells (James, 1964). The increased numbers of secretory granules evident in the mucous change may represent enhancement of the secretory activity of the crypt cells which continues as the cells migrate on to the villus (Bertalanffy and Nagy, 1961; MacDonald, Trier, and Everett, 1964). The production of mucus by the mucous cells could be the result of either direct stimulation or by the suppression of an inhibitory factor acting on the normal epithelial cells. Vitamin A is able to induce the transformation from stratified squamous epithelium of the skin of chick embryos to a mucus-secreting type in vitro (Fell, 1957), and might have a similar role in the induction of mucous change in the duodenum. A point of fundamental importance would be to establish that the mucous cells can actually secrete. What has been seen is certainly highly suggestive of secretory activity.

The presence of inflammatory changes in the mucosa involved by mucous change suggests that it is a reaction to tissue damage. Although there is a relationship with acid secretion it is not possible to say that it is acid as such which causes it. Equally well it might be part of the healing process which follows tissue damage.

Mucus itself can be accepted as a protective agent. Provided that mucous cells can release their secretion, it would be reasonable to assume that mucous change would protect the duodenal mucosa by preventing further damage and thereby promote the healing of duodenal ulcers.

We thank Mr I. B. Macleod and Dr J. Rhodes for providing some of the biopsy material, $\mathrm{Mr}$ W. Hawkins for his help with the histology, $\mathrm{Mr} \mathrm{H}$. Philip for printing the photomicrographs, Mrs A. McNeill for labelling the prints, Dr R. J. Prescott for his help with the statistics, the secretarial staff of the department for their assistance, and Dr Margaret A. Cochrane for help with the text.

The work was supported by a research grant from the Medical Research Council.

\section{References}

Bennett, H. S. (1963). Morphological aspects of extracellular polysaccharides. J. Histochem. Cytochem., 11, 14-23.

Bertalanffy, F. D., and Nagy, K. P. (1961). Mitotic activity and renewal rate of the epithelial cells of human duodenum. Acta anat. (Basel), 45, 362-370.

Brody, I. (1959). The kerantinization of epidermal cells of normal guinea pig skin as revealed by electron microscopy. J. ultrastruct. Res., 2, 482-511.

Culling, C. F. A. (1957). Handbook of Histopathological Technique. Butterworth, London.

Doniach, I., and Shiner, M. (1957). Duodenal and jejunal biopsies. II. Histology. Gastroenterology, 33, 71-86.

Duve, C. de, and Wattiaux, R. (1966). Functions of lysosomes. Ann. Rev. Physiol., 28, 435-492.

Echlin, P. (1964). Intra-cytoplasmic membranous inclusions in the blue-green alga, Anacystis nidulans. Arch. Mikrobiol., 49, 267-274.

Farquhar, M. G., and Palade, G. E. (1963). Junctional complexes in various epithelia. J. Cell Biol., 17, 375-412.

Fawcett, D. W. (1958). The identification of particulate glycogen and ribonucleoprotein granules in electron micrographs. (Abstr.) J. Histochem. Cytochem., 6, 95-96.

Fell, H. B. (1957). The effect of excess vitamin A on cultures of embryonic chicken skin explanted at different stages of differentiation. Proc. Roy. Soc. B., 146, 242-256.

Florey, H. W., and Harding, H. E. (1935). The healing of artificial defects of the duodenal mucosa. J. Path. Bact., 40, 211-218.

Florey, H. W., Jennings, M. A., Jennings, iD. A., and O'Connor, R. C. (1939). The reactions of the intestine of the pig to gastric juice. J. Path. Bact., 49, 105-123.

Freeman, J. A.(1966). Goblet cell fine structure. Anat. Rec., 154, 121147.

Glauert, A. M., Rogers, G. E., and Glauert, R. H. (1956). A new embedding medium for electron microscopy. Nature (Lond.), 178, 803.

Goel, S. C., and Jurand, A. (1969). The structures at the epithelioconnective tissue junction: a comparison of light and electron microscopic observations. Proc. roy. Soc. Edinb. B., 71, 1-13.

Ito, S. (1965). The enteric surface coat on cat intestinal microvilli. J. Cell. Biol., 27. 475-491.

James, A. H. (1963). Gastric epithelium in the duodenum of a patient with gastric hyperacidity. Proceedings of the 2nd World Congress of Gastroenterology, Munich, 1962, vol. 2, pp. 540-543. Karger, Basle and New York.

James, A. H. (1964). Gastric epithelium in the duodenum. Gut, 5, 285-294.

Johnston, D., and Jepson, K. (1967). Use of pentagastrin in a test of gastric acid secretion. Lancet, 2, 585-588.

Kay, D. H., Editor (1965). Techniques for Electron Microscopy, 2nd ed, Blackwell, Oxford.

Latta, H., and Hartmann, J. F. (1950). Use of a glass edge in thin sectioning for electron microscopy. Proc. Soc. exp. biol. (N.Y.), 74, 436-439.

Lawrie, J. H., Smith, G. M. R., and Forrest, A. P. M. (1964). The histamine-infusion test. Lancet, 2, 270-273.

Ledbetter, M. C., and Porter, K. R. (1963). A "microtubule" in plant cell fine structure. J. Cell Biol., 19, 239-250.

Lillibridge, C. B. (1964). The fine structure of normal human gastric mucosa. Gastroenterology, 47, 269-290.

MacDonald, W. C., Trier, J. S., and Everett, N. B. (1964). Cell proliferation and migration in the stomach, duodenum, and rectum of man: radioautographic studies. Gastroenterology, 46, 405-417.

McManus, J. F. A. (1946). Histological demonstration of mucin after periodic acid (Letter). Nature (Lond.), 158, 202.

Mayer, P. (1904). Notiz Über Hämateīn und Hämalaun. $Z$. wiss. Mikr., 20, 409-411.

Multicentre Pilot Study (1967). Pentagastrin as a stimulant of maximal gastric acid response in man. Lancet, 1, 291-295.

Palade, G. E. (1952). A study of fixation for electron microscopy. J. exp. Med., 95, 285-298.

Reynolds, E. S. (1963). The use of lead citrate at high pH as an electron-opaque stain in electron microscopy. J. Cell Biol., 17, 208-212.

Rhodes, J. (1964). Experimental production of gastric epithelium in the duodenum. Gut, 5, 454-458.

Rhodes, J., Evans, K. T., Lawrie, J. H., and Forrest, A. P. M. (1968). Coarse mucosal folds in the duodenum. Quart. J. Med., 37, 151-169. 
Sabatini, D. D., Bensch, K., and Barrnett, R. J. (1963). Cytochemistry and electron microscopy: the preservation of cellular ultrastructure and enzymatic activity by aldehyde fixation. J. Cell Biol., 17, 19-58.

Sörensen, S. P. L. (1909). Enzymstudien. 11, Uber die Messung und die Bedeutung der Wasserstoffionenkonzentration bei enzymatischen Prozessen. Biochem., Z., 21, 131-200.

Surgical Research Society (1972). Terms and abbreviations in gastric operations and acid tests. Gut, 13, 673.

Trier, J. S. (1963). Studies on small intestine crypt epithelium. 1.
The fine structure of the crypt epithelium of the proximal small intestine of fasting humans. J. Cell Biol., 18, 599-620.

Trier, J. S. (1964). Studies on small intestine crypt epithelium. 11. Evidence for and mechanisms of secretory activity by undifferentiated crypt cells of the human small intestine. Gastroenterology, 47, 480-495.

Trier, J. S., and Rubin, C. E. (1965). Electron microscopy of the small intestine: a review. Gastroenterology, 49, 574-603.

Trump, B. F., Smuckler, E. A., and Benditt, E. D. (1961). A method for staining epoxy sections for light microscopy. J. ultrastruct. Res., 5, 343-348. 